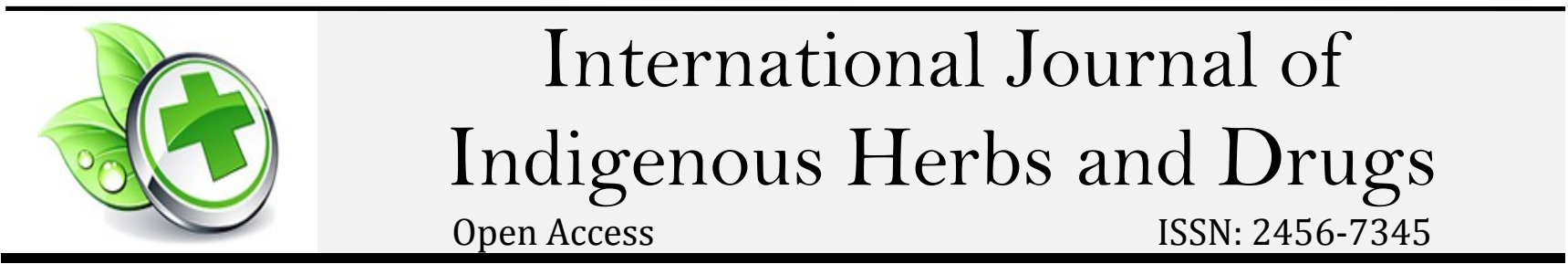

\title{
Formulation \& invitro evaluation of controlled release tablets of oxcarbazepine
}

N.Phrudvish*1, T.Malyadri², Ch.Saibabu ${ }^{3}$

1 Department of Pharmaceutics, M.L. College of Pharmacy, S. Konda-523101

2 Assistant professor, Department of Pharmaceutics, M.L. College of Pharmacy, S. Konda-523101

3 Head, Department of Pharmaceutics, M.L. College of Pharmacy, S. Konda-523101

\begin{tabular}{ll}
\hline Article Info : & Abstract \\
\hline $\begin{array}{l}\text { Article History } \\
\text { Received on: 16-04-2021 }\end{array}$ & $\begin{array}{l}\text { The present research project aimed to develop a Control release oral Oxcarbazepine tablets by } \\
\text { using Polymers likeTamarind gum, Xanthan gum, HPMC K4M, and HPMC K 15M were used for } \\
\text { Revised on : 30-05-2021 } \\
\text { Accepted on : 05-06-2021 }\end{array}$ \\
\hline \\
formulations were prepared and evaluated for pre-compression and post-compression \\
parameters, and all the results were found to be within the limits. From the drug and \\
excipients compatibility studies(FT-IR) it was confirmed that the drug and excipients have any \\
interactions. The in vitro dissolution studies revealed that the F12 formulation containing \\
18\% of HPMC K4M \& 18\% of HPMC K15M controls the drug release up to 12hours. So F12 \\
formulation was considered to be suitable for the formulation of Oxcarbazepine controlled- \\
release tablets at 18\% concentration of HPMC K4M \& 18\% concentration of HPMC K15M and \\
the drug release kinetics revealed that the F12 formulation shows a super case II transport \\
mechanism.
\end{tabular}

Keywords: Oxcarbazepine,HPMC K4M, HPMC K 15M, Tamarind gum, Xanthan gum, FT-IR.

This article is licensed under a Creative Commons Attribution-Non Commercial 4.0 International License. Copyright (C) 2021 Author(s) retain the copyright of this article.

*Corresponding Author

N.Phrudvish

Email: malyapharma22@gmail.com

Doi: https://doi.org/10.46956/ijihd.vi.161

Production and Hosted By

Saap.org.in

\section{Introduction}

Oral drug delivery is the most widely utilized route of administration among all the routes that have been explored for systemic delivery of drugs via pharmaceutical products of different dosage form. Oral route is considered most natural, convenient and safe due to its ease of administration, patient acceptance, and cost effective manufacturing process. Pharmaceutical products designed for oral delivery are mainly immediate release type or conventional drug delivery systems, which are designed for immediate release of drug for rapid absorption [1]. Controlled release dosage form is a dosage form that release one or more drugs continuously in predetermined pattern for a fixed period of time, either systemically or locally to specified target organ. Greater attention is paid on development of oral controlled release drug delivery systems due to flexibility in designing of dosage form. The main challenges to oral drug delivery systems are to deliver a drug at therapeutically effective rate to desirable site, modulation of GI transit time and minimization of first pass elimination. Control release dosage form provides better maintenance of optimal and effective drug level for prolonged duration with less dosing frequency and side effects [2,3]. Historically, oral drug administration has been the predominant route for drug delivery. It is known to be the most popular route of drug administration due to the fact the gastrointestinal physiology offers more flexibility in dosage form design than most other routes A major challenge for the pharmaceutical industry in drug development is to produce safe and efficient drugs, therefore properties of drugs and the way in which they are delivered must be optimised [4,5]. A controlled release drug delivery system delivers the drug locally or systemically at a predetermined rate for a specified period of time The goal of such systems is to provide desirable delivery profiles that can achieve therapeutic plasma levels. Drug release is dependent on polymer properties, thus the application of these properties can produce well characterised and 
reproducible dosage forms [6,7]. The basic rationale of a controlled release drug delivery system is to optimize the biopharmaceutics, pharmacokinetics, and pharmacodynamics properties of a drug in such a way that its utility is maximized through reduction in side effects and cure or control of disease condition in the shortest possible time by using smallest quantity of drug, administered by most suitable route. The immediate release drug delivery system lacks some features like dose maintenance, controlled release rate and site targeting. An ideal drug delivery system should deliver the drug at a rate dictated by the need of body over a specified period of treatment $[8,9,10]$. Oxcarbazepine 11 is an anti-epileptic medication used in the treatment of partial onset seizures that was first approved for use in the United States in 2000. It is a structural derivative of carbamazepine and exerts a majority of its activity via a pharmacologically active metabolite, MHD, which exists as a racemate in the blood - a pro-drug of the more active (S)-enantiomer is also marketed as a separate anti-epileptic under the name eslicarbazepine Compared to other anti-epileptic drugs, which are generally metabolized via the cytochrome P450 system, oxcarbazepine has a reduced propensity for involvement in drug-drug interactions owing to its primarily reductive metabolism.

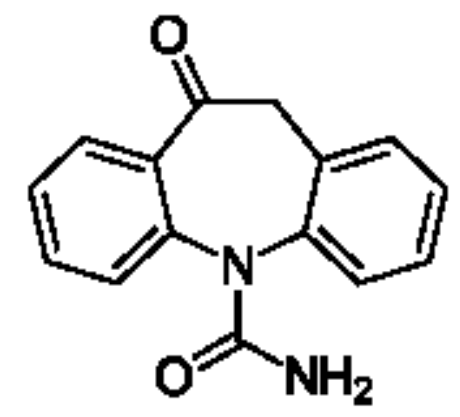

Fig 01: Chemical structure of oxcarbazepine

\section{Materials}

Oxcarbazepine from B.M.R Chemicals,Hyderabad, HPMC K4M ,HPMC K15 M from Strides arcolab, Bangalore,Tamarind gum ,Xanthum gum from Himedia laboratory. Mumbai ,PVP K 30, Magnesium Stearate, Micro Crystalline cellulose from Lobachemiepvt.ltd, Mumbai.

\section{Instruments}

UV-Vis Spectrophotometer from PG Instruments ,FTIR 1700S Spectrophotometer from Shimadzu, Japan, Dissolution test apparatus TDT-08T Dissolution Tester (USP) from LAB India DS-8000 ,Test Sieve (No.16, 22, 40, 60, 80) from Scientific Engineering Corp. Delhi ,Tablet punching machine (Rimek mini press-1) ( 10 stations) from Karnavati Engineering Ltd, Mehsana, Gujarat.

\section{Methodology}

Preformulationstudies [12-13]

Preformulation test ingisan investigation of physical and chemical properties of drug substances alone and when combined with pharmaceutical excipients. It is the first step in the ratio development of dosage form.

\section{a. Solubility \\ Solubility of Oxcarbazepine.}

Solubility studies were performed by taking excess amount of Oxcarbazepine in beakers containing the solvents. The mixtures were shaken for $24 \mathrm{hrs}$ at regular intervals.The solutions were filtered by using whattmann's filter paper gradeno.41.The filtered solutions are analyzed by spectrophotometrically.

\section{b. Compatibility Studies}

Compatibility study with excipients was carried out by FTIR.The pure drug and its formulations along with excipients were subjected to FTIR studies.In the present study, the potassium bromidedisc (pellet) method was employed.

\section{c. Identification of Oxcarbazepine [14]}

\section{Determination of UV spectrum of Oxcarbazepine}

$10 \mathrm{mg}$ of Oxcarbazepine was dissolved in $10 \mathrm{ml}$ of buffers so as to get a stock solution of $1000 \mu \mathrm{g} / \mathrm{ml}$ concentration. From the above stock solution pipette out $1 \mathrm{ml}$ of the solution and makeup the volume to $10 \mathrm{ml}$ using buffer to get the concentration of $100 \mu \mathrm{g} / \mathrm{ml}$ concentration. From this stock solution pipette out $2.5 \mathrm{ml}$ of the solution and makeup the volume to $10 \mathrm{ml}$ using buffer to get the concentration of $25 \mu \mathrm{g} / \mathrm{ml}$ concentration, this solution was scanned under UV Spectroscopy using 200-400nm.

\section{Preparation of Standard Calibration Curve of Oxcarbazepine \\ Preparation of Standard Calibration Curve of Oxcarbazepine in pH 1.2}

\section{A. Preparation of Stock Solution}

$10 \mathrm{mg}$ of Oxcarbazepine was dissolved in $10 \mathrm{ml}$ of $\mathrm{pH} 1.2$ buffers so as to get a stock solution of $1000 \mu \mathrm{g} / \mathrm{ml}$ concentration.

\section{B. preparation Standard Solution}

$1 \mathrm{ml}$ of stock solution was diluted to $10 \mathrm{ml}$ with $\mathrm{pH}$ 1.2 buffer in $10 \mathrm{ml}$ volumetric flask this gives a concentration of $10 \mu \mathrm{g} / \mathrm{ml}$. Aliquot of standard drug solutions were prepared by withdrawing 0.5 , $1,1.5,2,2.5$ and $3 \mathrm{ml}$ and transferred in to $10 \mathrm{ml}$ volumetric flask and were diluted up to the mark with pH 1.2 buffer. This gives the final concentration of $5,10,15,20,25$ and $30 \mu \mathrm{g} / \mathrm{ml}$ of Oxcarbazepine respectively. The absorbances of the solution were measured against $\mathrm{pH} 1.2$ as blank using UV visible spectrophotometer. The absorbance values were plotted against concentration $(\mu \mathrm{g} / \mathrm{ml})$ to obtain the standard calibration curve.

Preparation of Standard Calibration Curve of Oxcarbazepine in $\mathrm{pH} 6.8$

\section{A. Preparation of Stock Solution}

$10 \mathrm{mg}$ of Oxcarbazepine was dissolved in $10 \mathrm{ml}$ of pH 6.8 buffer so as to get a stock solution of $1000 \mu \mathrm{g} / \mathrm{ml}$ concentration 


\section{B. preparation Standard Solution}

$1 \mathrm{ml}$ of stock solution was diluted to $10 \mathrm{ml}$ with $\mathrm{pH} 6.8$ buffer in $10 \mathrm{ml}$ volumetric flask this gives a concentration of $10 \mu \mathrm{g} / \mathrm{ml}$. Aliquot of standard drug solutions were prepared by withdrawing 0.5, 1, 1.5, 2, 2.5 and $3 \mathrm{ml}$ and transferred in to $10 \mathrm{ml}$ volumetric flask and were diluted up to the mark with $\mathrm{pH} 6.8$ buffer. This gives the final concentration of 5 , $10,15,20,25$ and $30 \mu \mathrm{g} / \mathrm{ml}$ of Oxcarbazepine respectively. The absorbances of the solution were measured against $\mathrm{pH}$ 6.8 as blank using UV visible spectrophotometer. The absorbance values were plotted against concentration $(\mu \mathrm{g} / \mathrm{ml})$ to obtain the standard calibration curve.

\section{Preparation ofoxcarbazepine controlled releasematrix tablets [15-18]}

Controlled releasetablets ofOxcarbazepine wereprepared bydirect compression method usingvariable concentrations of different polymers likeHPMCK4M, HPMCK15M, Tamarind gum and Xanthan gum. Direct compression methodis widely employed method forproduction of compressed tablets.

\section{Direct compression}

In this process the tablets are compressed directly from powder blends of active ingredient and suitable excipients, which will flow uniformly in to the die cavity and forms a firm compact.

\section{Brief manufacturing procedure for the preparation of tablets}

Step 1- Weighed all the ingredients separately.

Step 2- The drug and the other excipients were passed through 40\# sieve together and blended for 10 minutes.

Step 3- The magnesium stearate was passed through 60\# sieve and added to the blend of step2 and blended for 5 minutes.

Step 4- Compressed the blend of step 3 in to tablets by using $8.5 \mathrm{~mm}$, round punches.

Table 01: Tablet composition of different formulations of Oxcarbazepine controlled release tablets

\begin{tabular}{|c|c|c|c|c|c|c|c|c|c|c|c|c|}
\hline \multirow{2}{*}{$\begin{array}{c}\text { Ingredients } \\
\text { (mg) }\end{array}$} & \multicolumn{12}{|c|}{ Formulation Code } \\
\hline & F1 & F2 & F3 & F4 & F5 & F6 & F7 & F8 & F9 & F10 & F11 & F12 \\
\hline Oxcarbazepine & 150 & 150 & 150 & 150 & 150 & 150 & 150 & 150 & 150 & 150 & 150 & 150 \\
\hline Tamarind gum & 17.5 & - & - & - & 35 & - & - & - & 26.25 & - & - & - \\
\hline Xanthan gum & - & 17.5 & - & - & - & 35 & - & - & 26.25 & 26.25 & 26.25 & - \\
\hline HPMC K4M & - & - & 17.5 & - & - & - & 35 & - & - & 26.25 & - & 26.25 \\
\hline HPMC K15M & - & - & - & 17.5 & - & - & - & 35 & - & - & 26.25 & 26.25 \\
\hline PVP K30 & 15 & 15 & 15 & 15 & 15 & 15 & 15 & 15 & 15 & 15 & 15 & 15 \\
\hline Micro. Cellulose & 161.5 & 161.5 & 161.5 & 161.5 & 144 & 144 & 144 & 144 & 126.5 & 126.5 & 126.5 & 126.5 \\
\hline Mg stearate & 3 & 3 & 3 & 3 & 3 & 3 & 3 & 3 & 3 & 3 & 3 & 3 \\
\hline Talc & 3 & 3 & 3 & 3 & 3 & 3 & 3 & 3 & 3 & 3 & 3 & 3 \\
\hline Total wt.(mg) & 350 & 350 & 350 & 350 & 350 & 350 & 350 & 350 & 350 & 350 & 350 & 350 \\
\hline
\end{tabular}

\section{EvaluationParameters $[19,20]$}

\section{Pre CompressionParameters}

A. Bulk density $\left(\mathrm{D}_{\mathrm{b}}\right)$

It is the ratio of powder to bulk volume.The bulk density depends on particle size distribution, shape and cohesiveness of particles. Accurately weighed quantity of powder was carefully pour edin to graduated measuring cylinder through large funnel and volume was measured which is called initial bulk volume. Bulk density is expressed in gm/ccand is given by,

$\mathrm{D}_{\mathrm{b}}=\mathrm{M} / \mathrm{V}_{\mathrm{O}}$

Where, $\mathrm{D}_{\mathrm{b}}=$ Bulk density $(\mathrm{gm} / \mathrm{cc})$
$\mathrm{M}$ is the mass ofpowder ( $\mathrm{g}$ )

$\mathrm{V}_{\mathrm{O}}$ is thebulk volume ofpowder(cc)

\section{B. Tapped density $\left(D_{t}\right)$}

Tengrams of powder was introduced into a clean,dry $100 \mathrm{ml}$ measuring cylinder.The cylinder wasthen tapped 100 times from a constant height and tapped volume was read. It is expressed ingm/cc and is given by,

$\mathrm{D}_{\mathrm{t}}=\mathrm{M} / \mathrm{V}_{\mathrm{t}}$

Where, $D_{t}=$ Tapped density (gm/cc) $M$ is the mass of powder (g)

$\mathrm{V}_{\mathrm{t}}$ is the tapped volume of powder(cc) 
C. Compressibility index:

The compressibility of the powder was determined bythe Carr's compressibility index.

$$
\mathrm{CI}=\frac{\rho_{\text {tap }}-\rho_{\text {bulk }}}{\rho_{\text {tap }}} \times 100
$$

where

$\rho$ tap is the tap density and $\rho$ bulk is the bulk density.

Table 02: Relation between the Carr'sindex of powder and its flow characteristics

\begin{tabular}{|c|c|c|}
\hline Sr.No. & Carr's index & Type of flow \\
\hline 1. & $5-15$ & Excellent \\
\hline 2. & $12-15$ & Good \\
\hline 3. & $18-21$ & Fair \\
\hline 4. & $23-30$ & Poor \\
\hline 5. & $33-38$ & Verypoor \\
\hline 6. & $>40$ & Extremelypoor \\
\hline
\end{tabular}

\section{Hausner ratio:}

Hausner ratio = tapped density $/$ bulk density

Values of Hausner ratio; <1.25: goodflow >1.25: poorflow If Hausner ratio is between 1.25-1.5,flow can be improved by addition of glidants.

\section{E. Angleofrepose ( $\theta$ )}

It is defined as the maximum angle possible between the surface of pile of the powder and the horizontal plane. Fixed funnel method was used. A funnel was fixed with its tipata given height (h), above a flat horizontal surface on which agraph paper was placed. Powder was carefully poured through a funnel till the apex of the conicalpile just touches the tip of funnel. The angle of repose was then calculated using the formula,

$$
\theta=\tan ^{-1}\left(\frac{h}{r}\right)
$$

where, $\theta=$ angle of repose

$\mathrm{h}=$ height of pile, $\mathrm{r}=$ radius of thebaseof thepile.

Table 03: Comparison between angles of reposes and flow property

\begin{tabular}{|c|c|}
\hline Angle of Repose & Flow \\
\hline$<25$ & Excellent \\
\hline $25-30$ & Good \\
\hline $30-40$ & $\begin{array}{c}\text { Moderate (addition of 0.2\% glidant } \\
\text { required) }\end{array}$ \\
\hline$>40$ & Poor \\
\hline
\end{tabular}

\section{Post CompressionParameters [21-22]}

\section{A. Thickness and diameter}

Control of physical dimension of the tablet such as thickness and diameter is essential for consumer acceptance and tablet uniformity.The thickness and diameter of the tablet was measured usingVerniercalipers.It is measured in $\mathrm{mm}$.

\section{B. Hardness}

The Mansan to hardness tester was used to determine the tablet hardness. The tablet was held betweena fixed and moving jaw. Scale was adjusted to zero;load was gradually increased until the tablet fractured.The value of the load atthat point gives ameasure of hardness of the tablet. Hardness was expressed in $\mathrm{Kg} / \mathrm{cm}^{2}$.

\section{Friability (F)}

Tablet strength was tested by Friabilator USPEF-2. Preweighed tablets were allowed for 100 revolutions (4min), taken out and were dedusted.The percentage weight loss was calculated by rewriting the tablets. The $\%$ friability was then calculated by,

$$
\mathrm{F}=\frac{\left(\mathrm{W}_{\text {initial }}\right)-\left(\mathrm{W}_{\text {final }}\right)}{\left(\mathrm{W}_{\text {intial }}\right)} \times 100
$$

\section{Weight variationtest}

The weight of the tablet being made in routinely measured to ensure thata tablet contains the proper amount of drug. The USP weight variation test was done by weighing 20 tablets individually,calculating the average weight and comparing the individual weights to the average. The tablet meet the USP test if not more than 2 tablets are out side the percentage limits and if no tablets differs by more than 2 times the percentage limit. USP official limits of percentage deviation of tablet are presented in the following table.

\section{Table 04: Weight variation limits}

\begin{tabular}{|c|c|c|}
\hline $\begin{array}{c}\text { Sr. } \\
\text { No. }\end{array}$ & $\begin{array}{c}\text { Averageweight of } \\
\text { tablet (mg) }\end{array}$ & $\begin{array}{c}\text { Maximum \% } \\
\text { difference allowed }\end{array}$ \\
\hline 1 & 130 orless & 10 \\
\hline 2 & $130-324$ & 7.5 \\
\hline 3 & 324 ormore & 5 \\
\hline \multicolumn{2}{c}{ PD $=\frac{\left(\mathrm{W}_{\text {avg }}\right)-\left(\mathrm{W}_{\text {iritial }}\right)}{\left(\mathrm{W}_{\text {avz }}\right)}$} \\
\end{tabular}

Where,

$\mathrm{PD}=$ Percentage deviation,

$\mathrm{W}_{\mathrm{avg}}=$ Average weight of tablet, $\mathrm{W}$ initial = individual weight of tablet.

\section{E. Uniformity of drug content}

Five tablets of various formulations were weighed individually and powdered. The powder equivalent to average weight of tablets was weighed and drug was extracted in different buffers, the drug content was determined using a UV/Visible Spectrophotometer (PG Instruments).

In-vitro releasestudy:

\begin{tabular}{|c|c|}
\hline Apparatus & $\begin{array}{c}\text { USP XXIV dissolution testing } \\
\text { apparatus II (paddle method) }\end{array}$ \\
\hline Dissolution & $0.1 \mathrm{~N} \mathrm{HCL}, 6.8 \mathrm{pH}$ phosphate buffer \\
\hline
\end{tabular}




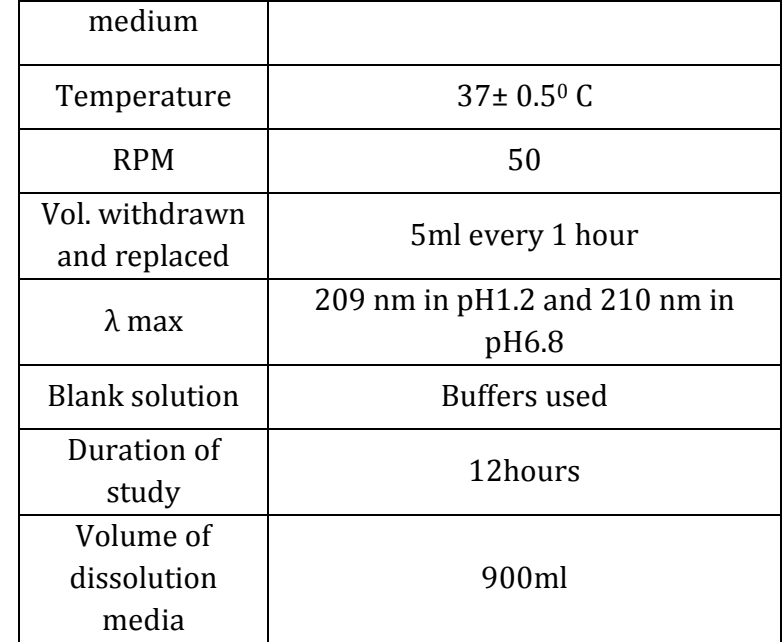

\section{Procedure}

The release rate of Oxcarbazepine from tablets was determined using The United States Pharmacopoeia (USP) XXIV dissolution testing apparatus II (paddle type). The dissolution test was performed using $900 \mathrm{ml}$ of $\mathrm{pH} \mathrm{1.2,} \mathrm{for}$ first 2 hours hours and followed by phosphate buffer $(\mathrm{pH}$ 6.8 ; $900 \mathrm{~mL}$ )for remaining hours at $37.5 \pm 0.5^{\circ} \mathrm{C}$ and 50 $\mathrm{rpm}$. A sample $(5 \mathrm{ml})$ of the solution was withdrawn from the dissolution apparatus hourly for 12 hours, and the samples were replaced with fresh dissolution medium. The samples diluted to a suitable concentration with respected dissolution medium. Absorbance of these solutions was measured at $210 \mathrm{~nm}$ using aUV-Visible Spectrophotometer (PG Instruments), Percentage of drug release was calculated.

\section{KineticAnalysisofIn-Vitro Release Rates of Controlled}

\section{ReleaseTablets [23,24]}

The resultsof invitro release profile obtained for all the formulations were plotted in modes ofdata treatment as follows:-

1. Zero-order kineticmodel- Cumulative \% drug released versus time.

2. First-order kinetic model-Log cumulative percent drug remain in gversus time.

3. Higuchi'smodel-Cumulative percent drug released versus squareroot of time.

4.Korsmeyer equation/Peppa'smodel-Log cumulative percent drug release dversus logtime.

\section{Zero Order Kinetics}

A zero-order release would be predicted by the following equation.

$$
\mathrm{dQ} / \mathrm{dt}=\mathrm{K}_{0}
$$

Where, $\quad Q=$ Drug released at time ' $\mathrm{t}$ '

$$
\mathrm{K}_{0}=\text { Zero-order rate constant (h-1). }
$$

When the data is plotted as cumulative percent drug released versus time, if the plot is linear then the data obeys zero-order release kinetics, with a slope equal to $\mathrm{K}_{0}$.

\section{First Order Kinetics}

To study the first order release rate kinetics, the release ra te data were fitted to the following equation,

$$
\mathrm{dQ} / \mathrm{dt}=\mathrm{K}_{1} \mathrm{Q}
$$

Where, $\quad Q=$ Amount of drug remained at time ' $t$ '
$\mathrm{K}_{1}=$ First-order rate constant ( $\left.\mathrm{h}-1\right)$.

When the data is plotted as log cumulative percent drug remaining versus time; yields a straight line, indicating that the release follows first-order kinetics. The constant 'K1' can be obtained by multiplying 2.303 with slope values.

\section{Higuchi model}

Higuchi developed several theoretical models to study the release of water soluble and low soluble drugs incorporated in semisolids and/or solid matrices. Mathematical expressions were obtained for drug particles dispersed in a uniform matrix behaving as the diffusion media. And the equation is,

$\mathrm{Qt}=\mathrm{KH} \cdot \mathrm{t} 1 / 2$

Where, $\mathrm{Qt}=$ amount of drug released in time $\mathrm{t}$,

$\mathrm{KH}=$ Higuchi dissolution constant

\section{Korsmeyer and Peppas model:}

The release rate from sustained release polymeric matrices can be described by

the equation proposed by korsmeyer et al.

$\mathrm{Q}=\mathrm{KKP}$ tn

Where, $Q=$ The amount of drug released at time ' $\mathrm{t}$ '

$\mathrm{K}_{\mathrm{KP}}=$ Kinetic constant incorporating structural and geometric characteristics of the tablets

' $n$ ' = The diffusional exponent, indicative of the release mechanism.

The release exponent, $n$, is the slope of log fraction of drug release versus log time curve.

Table 05: Mechanism ofDrug Releaseas perKorsmeyerEquation/Peppa's

Model:

\begin{tabular}{|c|c|c|}
\hline S. No. & N Value & Drug release \\
\hline 1 & 0.45 & Fickian release \\
\hline 2 & $0.45<\mathrm{n}<0.85$ & Non - Fickian release \\
\hline 3 & $>0.85$ & Case II transport \\
\hline
\end{tabular}

\section{Results and discussion}

Solubility studies

Table 06: Solubility studies of Oxcarbazepine:

\begin{tabular}{|c|c|}
\hline Solvent & Solubility \\
\hline Water & 0.856 \\
\hline $1.2 \mathrm{pH}$ buffer & 0.495 \\
\hline $7.4 \mathrm{pH}$ buffer & 0.548 \\
\hline $6.8 \mathrm{pH}$ buffer & 0.569 \\
\hline Solvent & Solubility \\
\hline Water & 0.856 \\
\hline $1.2 \mathrm{pH}$ buffer & 0.495 \\
\hline $7.4 \mathrm{pH}$ buffer & 0.548 \\
\hline $6.8 \mathrm{pH}$ buffer & 0.569 \\
\hline
\end{tabular}




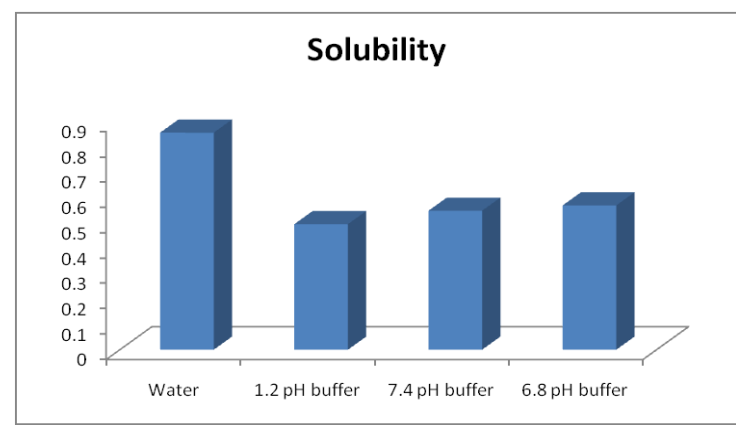

Fig 02: Solubility studies of Oxcarbazepine

\section{Determination of UV Spectrum}

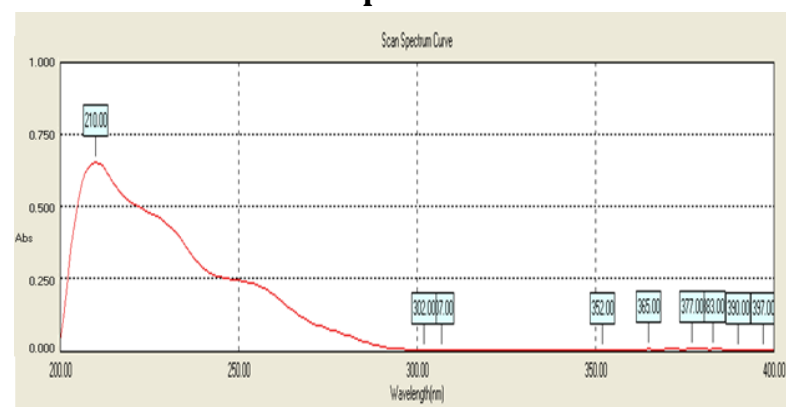

Fig.3: UV Spectrum of Oxcarbazepine

From the UV spectral analysis of Oxcarbazepine in

$10 \mu \mathrm{g} / \mathrm{ml}$ it was observed that the Oxcarbazepine has

$210 \mathrm{~nm}$.

Standard Calibration Curve of Oxcarbazepinein pH1.2

Table 07:Standard Calibration Curve of Oxcarbazepinein pH1.2:

\begin{tabular}{|c|c|}
\hline Concentration $(\boldsymbol{\mu g} / \mathbf{m l})$ & Absorbance \\
\hline 0 & 0 \\
\hline 5 & 0.109 \\
\hline 10 & 0.214 \\
\hline 15 & 0.309 \\
\hline 20 & 0.424 \\
\hline 25 & 0.521 \\
\hline 30 & 0.631 \\
\hline
\end{tabular}

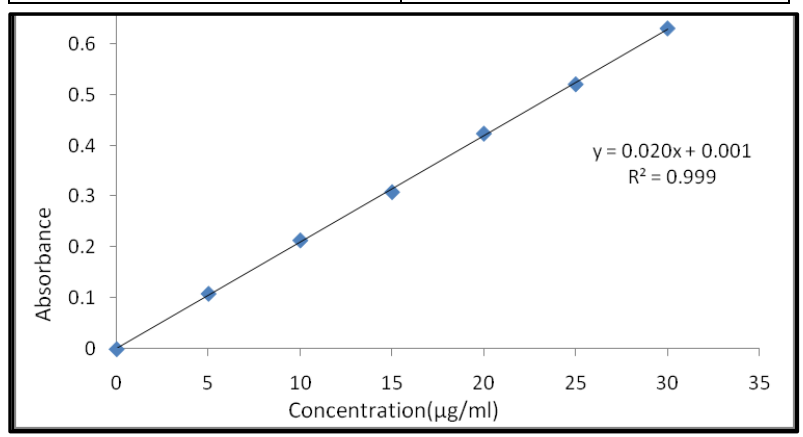

Fig 4: Standard calibration curve of Oxcarbazepine in $\mathrm{pH} 1.2$

Standard Calibration Curve of Oxcarbazepinein pH 6.8

Table 08: Standard Calibration Curve of Oxcarbazepinein pH 6.8

\begin{tabular}{|c|c|}
\hline Concentration $(\boldsymbol{\mu g} / \mathbf{m l})$ & Absorbance \\
\hline 0 & 0 \\
\hline 5 & 0.124 \\
\hline 10 & 0.259 \\
\hline 15 & 0.381 \\
\hline 20 & 0.509 \\
\hline 25 & 0.627 \\
\hline 30 & 0.759 \\
\hline
\end{tabular}

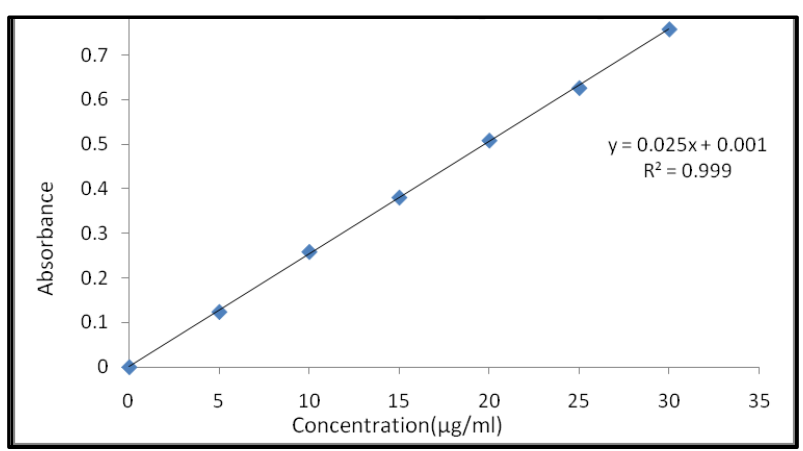

Fig 05: standard calibration curve Oxcarbazepinein pH6.8

FTIR studies

Spectrum of pure Oxcarbazepine

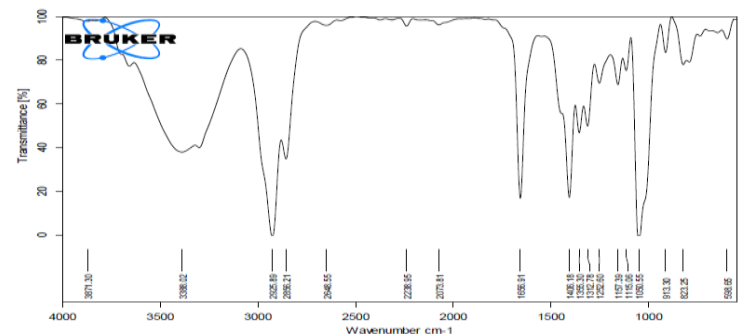

Fig 06: FTIR spectrumof pure Oxcarbazepine

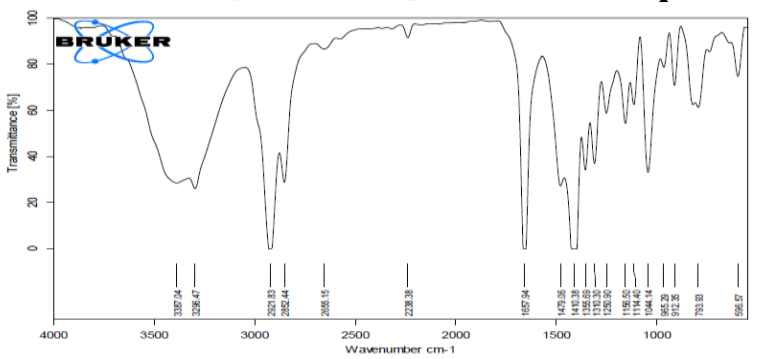

Fig 07:FTIR spectrum of Oxcarbazepine and Excipients

\section{Characterization of Drug}

\section{Melting Point}

Melting point of Oxcarbazepine was determined by capillary method. The melting 
point of Oxcarbazepine was found to be in the range $153-155^{\circ} \mathrm{C}$ which compiled with $\mathrm{BP}$ standards, indicating purity of the drug sample.

Evaluation of Oxcarbazepine controlled release matrix Tablets

Table 09: Pre Compression Parameters of Oxcarbazepine controlled release matrix Tablets

\begin{tabular}{|c|c|c|c|c|c|}
\hline FC & Angle of Repose & Bulk density & Tapped density & $\begin{array}{c}\text { Hausners } \\
\text { ratio }\end{array}$ & Carrs index \\
\hline F1 & $26.15 \pm 0.59$ & $0.282 \pm 0.44$ & $0.324 \pm 0.36$ & $1.14 \pm 0.22$ & $12.96 \pm 0.54$ \\
\hline F2 & $29.45 \pm 0.48$ & $0.270 \pm 0.16$ & $0.316 \pm 0.24$ & $1.17 \pm 0.54$ & $14.55 \pm 0.26$ \\
\hline F3 & $26.47 \pm 0.25$ & $0.286 \pm 0.84$ & $0.327 \pm 0.21$ & $1.14 \pm 0.26$ & $12.54 \pm 0.33$ \\
\hline F4 & $28.52 \pm 0.26$ & $0.279 \pm 0.26$ & $0.330 \pm 0.22$ & $1.18 \pm 0.87$ & $15.45 \pm 0.20$ \\
\hline F5 & $26.32 \pm 0.15$ & $0.274 \pm 0.22$ & $0.325 \pm 0.18$ & $1.19 \pm 0.62$ & $15.69 \pm 0.14$ \\
\hline F6 & $28.15 \pm 0.14$ & $0.288 \pm 0.14$ & $0.334 \pm 0.54$ & $1.16 \pm 0.48$ & $13.77 \pm 0.02$ \\
\hline F7 & $27.65 \pm 0.26$ & $0.272 \pm 0.02$ & $0.310 \pm 0.26$ & $1.14 \pm 0.34$ & $12.26 \pm 0.54$ \\
\hline F8 & $25.14 \pm 0.15$ & $0.268 \pm 0.97$ & $0.301 \pm 0.24$ & $1.12 \pm 0.22$ & $10.96 \pm 0.62$ \\
\hline F9 & $26.56 \pm 0.02$ & $0.266 \pm 0.47$ & $0.310 \pm 0.52$ & $1.17 \pm 0.04$ & $14.19 \pm 0.10$ \\
\hline F10 & $26.56 \pm 0.02$ & $0.276 \pm 0.56$ & $0.321 \pm 0.15$ & $1.16 \pm 0.15$ & $14.02 \pm 0.15$ \\
\hline F11 & $26.56 \pm 0.02$ & $0.269 \pm 0.14$ & $0.319 \pm 0.48$ & $1.19 \pm 0.26$ & $15.67 \pm 0.26$ \\
\hline F12 & $26.56 \pm 0.02$ & $0.259 \pm 0.25$ & $0.314 \pm 0.59$ & $1.21 \pm 0.47$ & $17.52 \pm 0.14$ \\
\hline
\end{tabular}

Post Compression Parameters of Oxcarbazepine controlled release matrix Tablets

Table 10: Physical properties oftabletformulation(F-1 toF-9):

\begin{tabular}{|c|c|c|c|c|c|}
\hline FC & $\begin{array}{l}\text { Avg.Wt } \\
\text { (mg) }\end{array}$ & $\begin{array}{c}\text { Thickness } \\
\text { (mm) }\end{array}$ & $\begin{array}{l}\text { Hardness } \\
\left(\mathrm{kg} / \mathrm{cm}^{2}\right)\end{array}$ & $\begin{array}{c}\text { Friability } \\
\text { (\%) }\end{array}$ & $\begin{array}{c}\text { Drug Content } \\
(\%)\end{array}$ \\
\hline F1 & $349.28 \pm 1.54$ & 3.59 & 8.45 & 0.33 & 96.14 \\
\hline $\mathrm{F} 2$ & $347.02 \pm 0.26$ & 3.66 & 8.55 & 0.25 & 95.54 \\
\hline F3 & $349.56 \pm 0.54$ & 4.11 & 8.63 & 0.45 & 97.26 \\
\hline $\mathrm{F} 4$ & $348.28 \pm 0.11$ & 3.71 & 8.66 & 0.82 & 98.64 \\
\hline F5 & $349.64 \pm 0.28$ & 3.81 & 8.53 & 0.01 & 99.41 \\
\hline F6 & $349.14 \pm 0.36$ & 3.93 & 8.84 & 0.64 & 97.26 \\
\hline F7 & $348.01 \pm 0.28$ & 3.65 & 8.83 & 0.92 & 95.14 \\
\hline F8 & $347.87 \pm 0.54$ & 3.45 & 8.42 & 0.48 & 95.21 \\
\hline F9 & $349.44 \pm 0.05$ & 3.98 & 8.58 & 0.21 & 96.58 \\
\hline F10 & $348.56 \pm 0.17$ & 4.15 & 8.88 & 0.61 & 97.41 \\
\hline F11 & $350.14 \pm 0.48$ & 3.87 & 8.48 & 0.84 & 97.49 \\
\hline F12 & $349.37 \pm 0.15$ & 3.66 & 8.71 & 0.57 & 98.65 \\
\hline
\end{tabular}

The average weight of the Oxcarbazepine tablets were found to be in the range of 347.02 to $350.14 \mathrm{mg}$.

Thickness of the Oxcarbazepine tablets were found to be in the range of 3.18 to $3.78 \mathrm{~mm}$.

Hardness of the Oxcarbazepine tablets were found to be in the range of 8.24 to $9.20 \mathrm{~kg} / \mathrm{cm}^{2}$.

Friabilityof the Oxcarbazepine tablets were found to be in the range of 0.10 to $0.84 \%$

Drug content of the Oxcarbazepine tablets were found to be in the range of 88.26 to $98.56 \%$.

In-vitro drug releasestudies

In-vitro drug release studies were carried out using USPXXII dissolution apparatus typeII(Lab India DS 8000 ) at $50 \mathrm{rpm}$. The dissolution medium consisted of $900 \mathrm{ml}$ of buffer, maintained at $37 \pm 0.5^{\circ} \mathrm{C}$. The drug release at different time intervals was measured at $210 \mathrm{~nm}$ using an ultraviolet visible spectrophotometer(PG Instruments). The study was performed in triplicate.

Table 11: In vitro dissolution studies

\begin{tabular}{|c|c|c|c|c|c|c|c|c|c|c|c|c|}
\hline $\begin{array}{l}\text { Time } \\
\text { (hrs) }\end{array}$ & F1 & F2 & F3 & F4 & F5 & F6 & F7 & F8 & F9 & F10 & F11 & F12 \\
\hline $\mathbf{0}$ & 0 & 0 & 0 & 0 & 0 & 0 & 0 & 0 & 0 & 0 & 0 & 0 \\
\hline 1 & 44.10 & 39.29 & 35.56 & $\begin{array}{c}30.2 \\
5\end{array}$ & $\begin{array}{c}19.7 \\
2\end{array}$ & 17.41 & $\begin{array}{c}33.2 \\
7\end{array}$ & $\begin{array}{c}26.6 \\
0\end{array}$ & $\begin{array}{c}19.5 \\
6\end{array}$ & $\begin{array}{c}30.5 \\
6\end{array}$ & $\begin{array}{c}24.8 \\
2\end{array}$ & $\begin{array}{c}13.5 \\
8\end{array}$ \\
\hline 2 & 53.52 & 44.26 & 31.7 & 40.8 & 26.6 & 24.48 & 45.9 & 39.8 & 26.4 & 36.0 & 46.3 & 26.2 \\
\hline
\end{tabular}




\begin{tabular}{|c|c|c|c|c|c|c|c|c|c|c|c|c|}
\hline & & & & 7 & 2 & & 8 & 6 & 8 & 6 & 8 & 5 \\
\hline 3 & 62.94 & 57.16 & 43.84 & $\begin{array}{c}52.4 \\
1\end{array}$ & $\begin{array}{c}35.9 \\
8\end{array}$ & 34.81 & $\begin{array}{c}59.2 \\
5\end{array}$ & $\begin{array}{c}50.1 \\
2\end{array}$ & $\begin{array}{c}37.7 \\
8\end{array}$ & $\begin{array}{c}49.4 \\
9\end{array}$ & $\begin{array}{c}55.9 \\
4\end{array}$ & $\begin{array}{c}32.4 \\
5\end{array}$ \\
\hline 4 & 73.36 & 69.65 & 55.98 & $\begin{array}{c}64.0 \\
3\end{array}$ & $\begin{array}{c}46.3 \\
4\end{array}$ & 45.15 & $\begin{array}{c}72.7 \\
7\end{array}$ & $\begin{array}{c}65.3 \\
8\end{array}$ & $\begin{array}{c}49.6 \\
5\end{array}$ & $\begin{array}{c}62.4 \\
9\end{array}$ & $\begin{array}{c}64.5 \\
0\end{array}$ & $\begin{array}{c}44.7 \\
8\end{array}$ \\
\hline 6 & 85.78 & 81.27 & 68.12 & $\begin{array}{c}75.6 \\
5\end{array}$ & $\begin{array}{c}58.3 \\
4\end{array}$ & 57.82 & $\begin{array}{c}85.8 \\
2\end{array}$ & $\begin{array}{c}76.6 \\
4\end{array}$ & $\begin{array}{c}57.7 \\
9\end{array}$ & $\begin{array}{c}70.4 \\
9\end{array}$ & $\begin{array}{c}73.0 \\
6\end{array}$ & $\begin{array}{c}56.2 \\
3\end{array}$ \\
\hline 8 & 98.25 & 97.56 & 0.26 & $\begin{array}{c}87.2 \\
8\end{array}$ & $\begin{array}{c}70.6 \\
3\end{array}$ & 69.89 & $\begin{array}{c}95.6 \\
2\end{array}$ & $\begin{array}{c}84.9 \\
0\end{array}$ & $\begin{array}{c}69.1 \\
8\end{array}$ & $\begin{array}{c}81.2 \\
6\end{array}$ & $\begin{array}{c}85.6 \\
2\end{array}$ & $\begin{array}{c}64.2 \\
5\end{array}$ \\
\hline 10 & & & 95.54 & $\begin{array}{c}98.1 \\
8\end{array}$ & $\begin{array}{c}83.2 \\
4\end{array}$ & 81.16 & & $\begin{array}{c}97.1 \\
6\end{array}$ & $\begin{array}{c}78.5 \\
9\end{array}$ & $\begin{array}{c}95.2 \\
2\end{array}$ & $\begin{array}{c}97.1 \\
8\end{array}$ & $\begin{array}{c}75.2 \\
6\end{array}$ \\
\hline 12 & & & & & & 93.49 & & & $\begin{array}{c}89.2 \\
6\end{array}$ & & & $\begin{array}{c}96.2 \\
6\end{array}$ \\
\hline
\end{tabular}

\section{In vitro drug release studies}

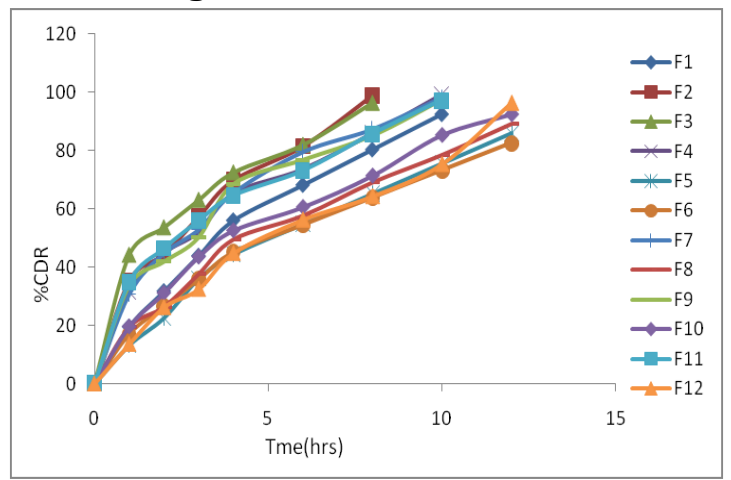

Fig 08:In Vitro Drug Release Studies of F1-F12 Formulations

Fig 09:In Vitro Drug Release Studies Of F1-F4

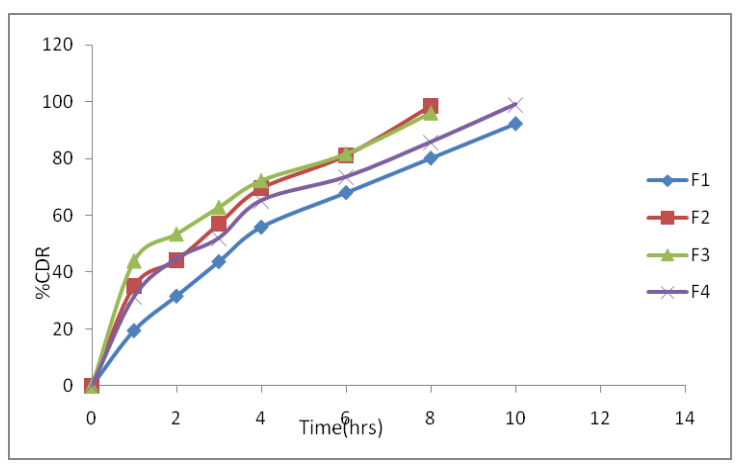

Formulations

Fig 10:In Vitro Drug Release Studies Of F5-F8

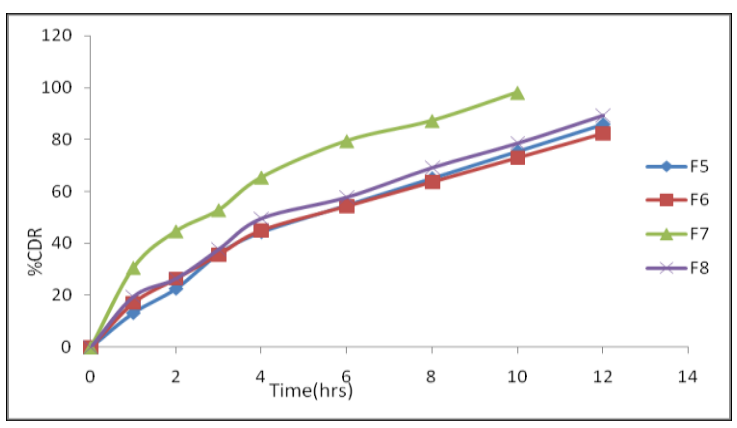

Formulations

Fig 11: In Vitro Drug Release Studies of

\section{F9-F12 Formulations}

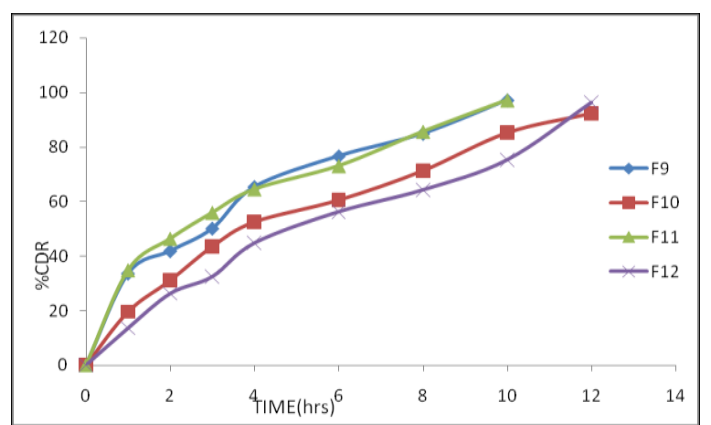

From the in vitro drug release studies of Oxcarbazepine controlled release tablets using HPMC K4M, HPMC K15M,Tamarind gum and Xanthan gum in different polymer ratios using MCC as a filler and PVP K30 as binder. Among the all 12 trails F1-F4 trails were formulated using HPMC K 4M, HPMC K15M and Tamarind gum and Xanthan gum with the ratio of 5\%. F1 formulation containing $5 \%$ of Tamarind gum shows $92.4 \%$ of drug release at the end of 10 hours, while F2 formulation containing $5 \%$ of Xanthan gum shows $98.65 \%$ of drug release at the end of 8hours, whereas F3 formulation containing 5\% of HPMC K4 M shows $96.20 \%$ of drug release at the end of 8hours, and F4 formulation containing 5\% of HPMC K15 M shows $99.08 \%$ of drug release at the end of 10 hours, Among all the four formulations (F1-F4)none of the formulations didn't controlled the drug release for 12 hours at $5 \%$ concentration. So further formulations were prepared by increasing their concentrations individually. Then F5-F8 trails were formulated using HPMC K 4M, HPMC K15M and Tamarind gum and Xanthan gum with the ratio of $10 \%$. F5 formulation containing $10 \%$ of Tamarind gum shows $85.78 \%$ of drug release at the end of 12 hours, while F2 formulation containing $10 \%$ of Xanthan gum shows $82.49 \%$ of drug release at the end of 12 hours, whereas F3 formulation containing 10\% of HPMC K4 M shows $98.12 \%$ of drug release at the end of 10 hours, and F4 formulation containing 10\% of HPMC K15 M shows $89.26 \%$ of drug release at the end of 12 hours, Among the above four formulations (F5-F8) none of the formulations didn't followed the criteria of controlled release drug 
delivery even at $10 \%$ concentration. So further formulations were prepared by combination of polymers. Then F9-10 trails were formulated using two different combination ratios of Tamarind gum \& Xanthan gum, the drug release was decreased with increase in the polymer concentration. F9 formulation containing $7.5 \%$ of Tamarind gum \& $7.5 \%$ of Xanthan gum shows $97.16 \%$ of drug release at the end of 10hours, while F10 formulation containing $7.5 \%$ of Xanthan gum \& $7.5 \%$ of HPMC K4M shows $92.26 \%$ of drug release at the end of 12 hours.But these two above formulation fails to produce reproducibility. Then F11 formulation containing $7.5 \%$ of Xanthan gum\& $7.5 \%$ of HPMC K15M shows $97.18 \%$ of drug release at the end of 10 hours, while F12 formulation containing $7.5 \%$ of HPMC K4M\& $7.5 \%$ of HPMC K15M shows $96.26 \%$ of drug release at the end of 12 hours. Among the all twelve formulations F12 formulation containing $7.5 \%$ of HPMC K4M\& $7.5 \%$ of HPMC K15M controls the drug release upto 12hours. So F12 formulation was considered to be suitable for the formulation of Oxcarbazepinecontrolled release tablets at 7.5\%concentration of HPMC K4M\& 7.5\%concentration of HPMC K15M. So the drug release kinetics were performed for the F12 formulation.

\section{Drug release kinetics}

Zero order

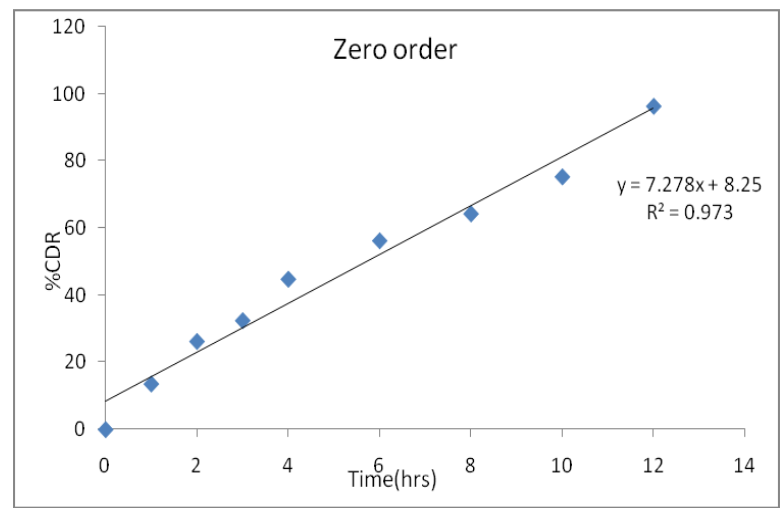

Fig 12: Zeroorder graph of optimized formulation

\section{First order}

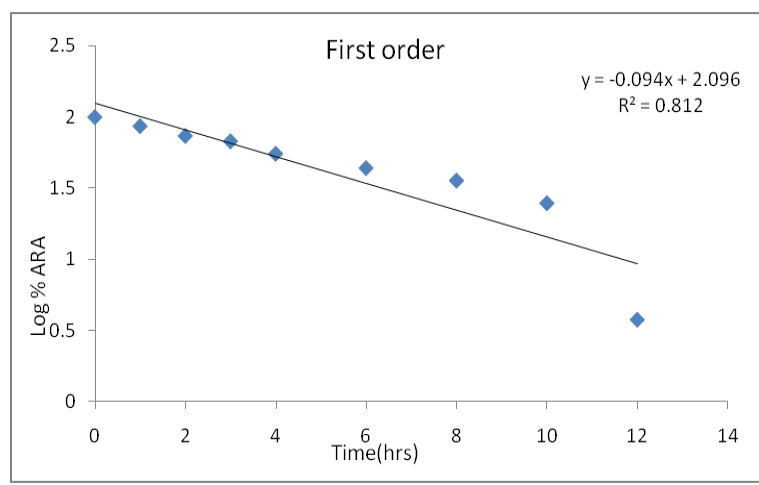

Fig 13: Firstorder graph of optimized formulation

\section{Higuchi plot}

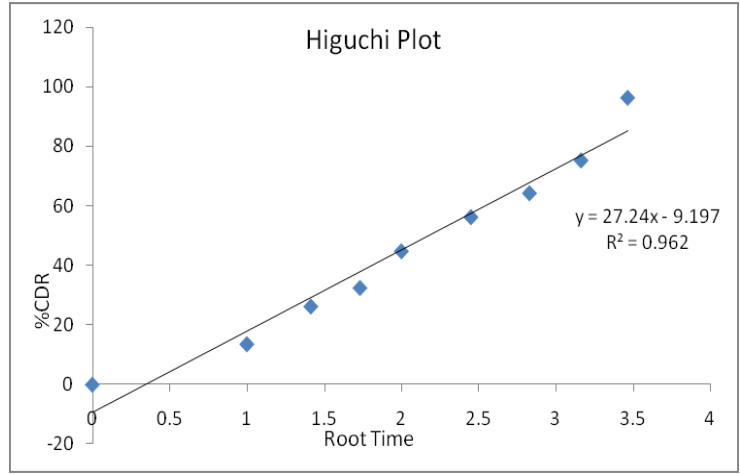

Fig 14: Higuchi graph of optimized formulation (F12)

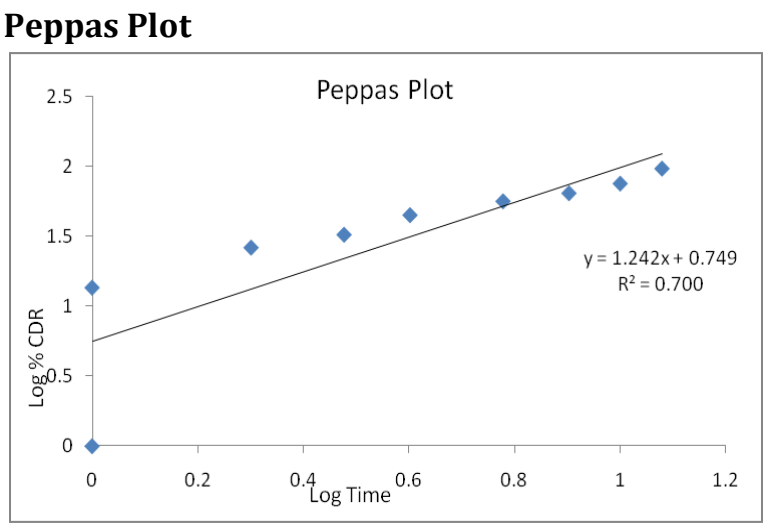

Fig 15: Peppas graph of optimized formulation (F12)

Table 12: Drug release kinetics

\begin{tabular}{|c|c|c|c|c|l|}
\hline \multicolumn{7}{|c|}{$\mathbf{R}^{2}$ values } & $\begin{array}{l}\text { n } \\
\text { val } \\
\text { ues }\end{array}$ \\
\hline $\begin{array}{c}\text { Formula } \\
\text { tion }\end{array}$ & $\begin{array}{c}\text { Zer } \\
\text { o } \\
\text { ord } \\
\text { er }\end{array}$ & $\begin{array}{c}\text { Firs } \\
\text { ord } \\
\text { er }\end{array}$ & $\begin{array}{c}\text { Higu } \\
\text { chi }\end{array}$ & $\begin{array}{c}\text { Korsm } \\
\text { eyer - } \\
\text { Peppas }\end{array}$ & $\begin{array}{l}\text { Kors } \\
\text { mey } \\
\text { er- } \\
\text { Pep } \\
\text { pas } \\
\text { (n) }\end{array}$ \\
\hline F12 & $\begin{array}{c}0.9 \\
73\end{array}$ & $\begin{array}{c}0.8 \\
12\end{array}$ & $\begin{array}{c}0.96 \\
2\end{array}$ & 0.700 & $\begin{array}{l}1.24 \\
2\end{array}$ \\
\hline
\end{tabular}

The invitro dissolution data for best formulation F12were fitted in different kinetic models i.e, zero order, first order, Higuchi and korsemeyer-peppas equation. Optimized formulation F12 shows $\mathrm{R}^{2}$ value 0.973 . As its value nearer to the ' 1 ' it is conformed as it follows the Zero order release. The mechanism of drug release is further confirmed by the korsmeyer and peppas plot, if $\mathrm{n}$ $=0.45$ it is called Case I or Fickian diffusion, $0.45<\mathrm{n}<$ 0.89 is for anomalous behavior or non-Fickian transport, $\mathrm{n}=0.89$ for case II transport and $\mathrm{n}>0.89$ for Super case II transport. The ' $n$ ' value is 1.242 for the optimised formulation (F12) i.e., $\mathrm{n}$ value was $>0.89$ this indicates super case transport.The release kinetics for the optimized formula are shown in table. 


\section{Summary and conclusion}

In this study controlled release matrix tablets of Oxcarbazepine were prepared by Direct compression method,using HPMCK4M, HPMCK15M, Tamarind gumand Xanthan gumpolymersasretardant. The pre compression and post compression parameters show that the values were found to be acceptable within the range. FT-IR studies revealed that the drug and excipients used weren't have any interactions. The drug-polymer ratio was found to influence the release of drug fromtheformulations. Different parameters like hardness, friability, weight variation, drug content uniformity, invitro drug release were evaluated. Among the all twelve formulations F12 formulation containing 7.5\% of HPMC K4M \&7.5\% of HPMC K15M controls the drug release upto 12hours. So F12 formulation was considered to be suitable for the formulation of Oxcarbazepine controlled release tablets at $7.5 \%$ concentration of HPMC K4M \&7.5\% concentration of HPMC K15M. So the drug release kinetics were performed for the F12 formulation. Based on these results formulation $\mathrm{F} 12$ was found to be the most promising formulations.The invitro dissolution data for best formulation F12 were fitted in different kinetic models i.e, zero order, first order, Higuchi and korsemeyer-peppas equation. Optimized formulation F12 shows $R^{2}$ value 0.973 . As its value nearer to the ' 1 ' it is conformed as it follows the Zero order release. The mechanism of drug release is further confirmed by the korsmeyer and peppas plot, if $\mathrm{n}=0.45$ it is called Case I or Fickian diffusion, $0.45<\mathrm{n}<0.89$ is for anomalous behavior or non-Fickian transport, $\mathrm{n}=0.89$ for case II transport and $n>0.89$ for Super case II transport.The ' $n$ ' value is 1.242 for the optimised formulation (F12) i.e., $n$ value was $>0.89$ this indicates super case transport.

\section{References}

1. Sathish Ummadi, B. Shravani, N. G. Raghavendra Rao, M. Srikanth Reddy, B. Sanjeev Nayak.Overview on Controlled Release Dosage Form. International Journal of Pharma SciencesVol. 3, No. 4 (2013): 258-269.

2. Brahmankar D.M. and Jaiswal S.B. (1995): "Biopharmaceutics and Pharmacokinetics" a Treatise. Vallabh Prakashan, First Edition; 336337.

3. Lachman Leon, Lieberman Herbert A., Kanig Joseph L. (1996) "The Theory and Practice of Industrial Pharmacy" Second edition, Varghese Publishing House; Bombay, 171-196.

4. Brahmankar DM, Jaiswal SB. Biopharmaceutics and Pharmacokinetics: Pharmacokinetics. 2nd ed. Vallabh Prakashan, Delhi: 2009; 399-401.

5. John C, Morten C, The Science of Dosage Form Design, Aulton: Modified release peroral dosage forms. 2nd ed. Churchill Livingstone. 2002; 290300.

6. Ali Nokhodchi, ShaistaRaja, Pryia Patel, and Kofi Asare-Addo.The Role of Oral Controlled Release
Matrix Tablets in Drug Delivery Systems.Bioimpacts. 2012; 2(4): 175-187.

7. John C, Morten C, The Science of Dosage Form Design, Aulton: Modified release peroral dosage forms. 2nd ed. Churchill Livingstone. 2002; 290300.

8. Sathish Ummadi, B. Shravani, N. G. Raghavendra Rao, M. Srikanth Reddy, B. SanjeevNayak.Overview on Controlled Release Dosage Form. International Journal of Pharma Sciences. Vol. 3, No. 4 (2013): 258-269.

9. Vyas S,P, Khar RK. Controlled Drug delivery: Concepts and Advances. Concepts and Advances.1st ed. Vallabh Prakashan, 2002, p,156189.

10. Shargel L, Yu ABC. Modified release drug products. In: Applied Biopharmaceutics and Pharmacokinetics. 4th ed. McGraw Hill.1999; 169-171.

11. AinleY, Paul JW. Handbook of pharmaceutical excipients. Mongraph 2nd edition. Lodon: PharmaceuticalPress; 2000:51.52, 128, 138-139, 257.113,19.

12. Indian pharamacopeia. Government ofIndia Ministry Health and Family Welfare. Delhi: Controlerof publication;1996:750,151.

13. Dollery C. Therapeutic drugs. London: Churchill Livingstone:1991;2:p7-25.

14. www.drugstore.com.

15. Hand book of excipients. Second edition. Ainley Wade\& PaulJ Weller. American Pharmaceutical Association. Washington.1994.

16. Lachman Leon, Lieberman HerbertA. Pharmaceutical Dosage Forms:Tablets.In: The Theory and Practice of Industrial Pharmacy. Leaand Febiger, U.S.A, 1991; 3rd edition:293345 .

17. Subrahmanyam CVS. Textbook of physical pharmaceutics. 2nd edi Delhi: Vallabaprakashan; 2003.p.180-234.

18. Korsemeyer RW, Peppas NA. Macromolecular and modeling aspects of swelling -controlled Systems. In: Mansdrofsz, RosemanTJ,ad, Controlled Release Delivery systems. NewYork,NY: Marcel Dekker; 1983:77.

19. ICH Q1A (R2) stability testing guidelines: stability testing of new drug substances andproducts. [Online]. 2003 [cited 2008 Nov10]; Availablefrom:

URL:http://www.tga.health.gov.au/docs/pdf/eu guide/inch/273699r2en.pdf

20. Reddy KR,Mutalik S,ReddyS.Once-Daily Sustained-Release Matrix Tablets of Nicorandil : Formulation and In Vitro Evaluation. AAPS Pharm Sci Tech.2003; 4(4):article61.

21. Murali Mohan BabuGV.et.al.,Development of new controlled released formulation of 
flurbiprofen,in-vitroin-vivo correlation".Ind J of Pharm Sci 2002 ;64(1):37-43.

22. NerkurJ, JunHW, ParkJC, ParkMO, Controlledrelease matrix tablets of ibuprofen using cellulose ethers and carrageenans: effect of formulation factors on dissolution rates. Eur J Pharm Biopharm 2005 61(1-2)56-68.

23. Marabathuni VJ, Dinesh P, Ravikumar R, Yamini P, Kiran PS, Hussain SP, Rao CM. Chitosan based sustained release mucoadhesive buccal patches containing amlodipine besylate (AMB). Asian J Res Pharm Sci. 2017 Jun 28;7:97-104.

24. Marabathuni VJ, Bhavani M, Lavanya M, Padmaja K, Madhavi N, Babu P, Rao CM. Formulation and evaluation of mouth dissolving Tablets of carbamazepine. Magnesium. 2017 Sep 27;15(30):15. 